\title{
Niche Overlap and Discrediting Acts: An Empirical Analysis of Informing in Hollywood
}

\author{
Giacomo Negro, ${ }^{\text {S Sasha Goodman }}{ }^{\mathrm{b}}$
}

a) Emory University; b) Northeastern University and Harvard University

Abstract: This article examines informing on others as a discrediting act between individual agents in a labor market. We conduct an empirical analysis of artists called to testify during the 1950s Congressional hearings into Communism in Hollywood, and multi-level regression models reveal that the odds of an artist informing on another increase when their career histories are more similar. The similarity reflects levels of niche overlap in the labor market. The finding that similarity contributes to discredit in the context of resource competition is compatible with a social comparison process, whereby uncertainty about performance leads more similar people to attend to and exclude one another to a greater extent.

Keywords: niche overlap; similarity; informing; blacklisting; Hollywood; film industry

Citation: Negro, Giacomo and Sasha Goodman. 2015. "Niche Overlap and Discrediting Acts: An Empirical Analysis of Informing in Hollywood." Sociological Science 2: 308-328.

Received: January 16, 2015

Accepted: March 5, 2015

Published: June 9, 2015

Editor(s): Jesper Sørensen, Gabriel Rossman

DOI: $10.15195 / \mathrm{v} 2 . a 15$

Copyright: (C) 2015 The Author(s). This open-access article has been published under a Creative Commons Attribution License, which allows unrestricted use, distribution and reproduction, in any form, as long as the original author and source have been credited. (0)(1)
$\mathrm{R}^{\mathrm{s}}$ ESEARCH going back at least sixty years has demonstrated that people who have common characteristics, such as age, education, race, occupation, and social status, are structurally similar (Lazarsfeld and Merton 1954). In a wide variety of social situations this similarity is associated with positively valued cognitive, emotional, and behavioral outcomes.

Surprisingly, less attention has been paid to negative outcomes caused by similarity, such as expressions of disfavor or discredit between individuals (exceptions include Sampson 1968 and Baker and Faulkner 2003). This article addresses this issue, and we argue that the probability of discredit is expected to increase with greater similarity. Situating the argument in known ecological and network theories about markets, we define a market as a system of niches in which individuals seek access to finite resources that sustain their livelihoods, such as jobs in a project, and occupy positions based on features related to resources, such as professional roles. When market agents have similar features, their niches overlap. This promotes social comparisons and, as resources are perceived to be limited, a competitive attitude; given the opportunity, these factors can result in discrediting acts.

The analysis focuses on 1950s U.S. House hearings that investigated the Hollywood film industry. Artists called to testify were asked to state any Communist affiliation and then to name others who were Communist. Many witnesses refused to cooperate with the Congressional committee and did not name anyone. Some artists gave names, and those they targeted experienced diminished opportunities to obtain jobs (Ceplair and Englund 1979; Pontikes, Negro, and Rao 2010). Using an original dataset culled from official reports and industry directories, our multi-level regression models analyze each testimony as an event that presents witnesses with a choice to inform on other Hollywood artists. We find that the odds that a witness will inform on another increase with the degree of similarity in their careers. The 
result holds net of prior affiliations with ideological Communist groups and of work collaborations also indicating that similarity and propinquity can have opposing effects on social relations in a market.

\section{Niche Overlap, Similarity, and Discrediting Acts}

Populations of humans and organizations occupy similar niches and compete with each other for their livelihoods when they depend on the same set of finite resources, such as space and capital for humans or top-ranked managers for organizations (Park, Burgess, and McKenzie 1925, Hawley 1950; Hannan and Freeman 1977; McPherson 1983; Aldrich 1999; Hannan, Pólos, and Carroll 2007).

Competition in niches evolves through stages (Hawley 1950). In the first stage, two or more persons or organizations emerge with a dependency on similar resources. In the second stage, the members of these groups adopt homogeneous production practices necessary to thrive. In the third stage, the pressure of congestion increases as the overall group or population size grows. Congestion is a positive function of niche overlap. When niche overlap increases, diffuse competition results in mobility, lower growth, or demise of the competitors that lack sufficient resources.

Previous studies put limited emphasis on how social agents deal with particular choices that precede such demographic outcomes. In markets and other social settings, the assumed intent of a competitor is to win access to finite resources to secure its wellbeing. In the ecological account, competitors typically behave honestly-and more so when resources abound and the wellbeing of one agent does not reduce the wellbeing of another.

However, when resources are congested, the livelihood of one agent comes at the expense of another. Hawley (1950:203) hints at the emergence of a fourth stage of competition in which contenders can develop ways "to make oblique attacks on the supply" of a competitor. To improve their own viability, social agents can choose to target competitors with antagonistic acts that imply the competitors' exclusion.

Antagonism may emerge from niche overlap, but ecological studies typically do not address questions such as when antagonism is more likely and between whom. Network studies of markets partly fill the conceptual gap because they infer competitive response from positions defined by social structural conditions surrounding each agent (White 1981; Burt 1982). Yet they agree with the basic premise in niche theory that agents are competitors in the same market to the extent that they depend on the same kinds of finite, differentiated resources. Competitive decisions emerge from the positions that agents occupy, based on the structure of relations they develop with one another.

This ecological-relational perspective then suggests that individual agents interpret one another's positions before choosing a course of action (White 1981; Hannan, Pólos, and Carroll 2007). The relations used to define market positions include direct contacts as well as abstract associations resulting from observations of one another's relations with people, objects, the built environment, and other identities (White 2008). We expect perceptions of market position similarity to influence individual responses to competition within the niche. 
Psychological research suggests that individuals compare themselves with others but tend to focus on comparisons with more similar people (Gilbert, Giesler, and Morris 1995). Garcia, Tor, and Schiff (2013) argue that observing similar features in other individuals increases social comparison concerns. Social comparison is linked to antagonistic behavior in at least two related ways: it promotes scrutiny so that agents compare themselves more with similar others, who are viewed as competitors; second, similarity becomes a motive for action because antagonizing a particular competitor will make the contested resources easier to acquire.

By fostering social comparisons and creating a motive, similarity can result in antagonistic acts, and in this article we focus on discredit as a form of antagonism. Kilduff et al. (2012) show that rivalry associated with being closely matched with another person increases Machiavellianism, over-reporting of performance, willingness to employ unethical negotiation tactics, and unsportsmanlike behavior. Garcia, Song, and Tesser (2010) find that subjects make negative job recommendations when other candidates in their comparison context surpass them on a relevant skill dimension. Uncertainty about performance leads agents to engage in rivalry towards outperforming as well as underperforming competitors, and similarities that are directly and indirectly related to performance matter (Garcia, Tor, and Gonzalez 2006).

The analysis presented next focuses on a crowded labor market, a situation where resources are finite and contested, and where career interests promote comparison concerns. Such a situation is amenable to a transition toward Hawley's fourth stage of oblique attacks. We define niche overlap as the degree of similarity along a range of features and affiliations related to acquiring resources. We expect that more similar positions within this labor market will create the conditions where agents tend to perceive more intense competition for jobs and, under the circumstances we specify, they will try to undermine one another. The main hypothesis is: greater niche overlap, reflected though greater similarity of career features in the labor market, will increase the likelihood that one market agent will initiate a discrediting act against another.

We consider four boundary conditions for this hypothesis. First, there is the caveat that discrediting acts between individuals cost time and material and social resources. These include the risk of retribution and reputational blowback. The context ought to make acceptable the net cost of initiating the discrediting act or present an opportunity that lowers it. As in our case, these opportunities occur when an authority, norm, institution, or powerful entity sanctions the antagonistic struggle; moreover, these situations include interactions that occur only once or where an anonymous attack can be made. Second, agents must be able to observe or have knowledge of others for social comparison to apply. Therefore, some level of information or hints about a target must flow to an agent. Third, environments must be viewed as competitive, and typically this occurs as markets become crowded and finite resources diminish (e.g., limited jobs or clients opportunities). Fourth, the situation should allow individuals to make choices for personal gain without requiring coordination in a larger group. 


\section{Informing in Hollywood}

In 1947, the House Committee on Un-American Activities (HUAC) announced a study of the issue of Communist subversion in motion pictures (Cogley 1956). HUAC issued subpoenas to 43 members of the Hollywood film industry requiring that they appear as witnesses in Washington. Nineteen of them announced they would not cooperate, and eleven of them were called to testify. Among the eleven were prominent artists such as writer Dalton Trumbo and director Edward Dmytryk. Ten among these witnesses refused to defer to the Committee and were cited for contempt of Congress. They were later sentenced to one year in jail.

In 1951, HUAC launched a second investigation of Hollywood and Communism, and more hearings were conducted until 1956. This time, dozens of witnesses were compelled to testify about their own activities and also to "name names," informing on others who might have participated in Communist organizations and events. Each named artist was then blacklisted from working in films.

Many witnesses remained "unfriendly" and did not cooperate with HUAC, usually invoking the Fifth Amendment's protection against self-incrimination while under oath. Nevertheless, there was a legal risk of perjury. Less than a year before the new hearings began, the Supreme Court ruled in Rogers $v$. United States (US 367) that once witnesses waived the privilege of silence when answering incriminating questions relating to themselves, they could not refuse to answer questions about others or else they could be indicted. Though thus pressured to participate, they were given a choice about whom to inform on.

Following White (1981:526), Faulkner and Anderson (1987:907) have described Hollywood's labor market as an ecological niche in which "crowds of competing social actors" vie for employment in film projects. Artists develop their careers by accumulating screen credits, and the labor market is organized around differentiated structures defined by positions in a web of professional roles, identities, and affiliations. The finite opportunities to work depend on the numbers and profiles of eligible people within such differentiated structures on each side of the market.

Faulkner and Anderson refer to a crowded market setting that can transition into antagonistic competition and Hawley's fourth stage of oblique attacks. Artists with similar professional and demographic features hold similar market positions and are-or at least are perceived to be-in competition for the same kinds of film projects. Hollywood is an industry where mutual monitoring is the norm, so artists engage in social comparisons with others in similar market positions.

HUAC created an opportunity to "pick up the sword" against a potential competitor for a job and "find a shield" from an attack. By organizing trials, the committee reduced the material and social costs of discrediting and retaliating. Informers risked employment discrimination, loss of self-esteem, and potential social penalties, particularly loss of friendship (Navasky 1980). However, giving names to HUAC was framed by authorities as a patriotic deed and so it was publicly legitimated. The informer was characterized as a hero, and the targets were presented as "cunning participants in an international espionage conspiracy" (Navasky 1980:424). 
Although under-emphasized in historical accounts and never analyzed quantitatively, some observers hint that competition for film jobs may have affected the decisions of witnesses to inform on others. In an interview with film historian Patrick McGilligan, director Jules Dassin said that friendly witnesses put "career before honor" (McGilligan and Buhle 1997:213). Other observers suggest that career rivalries were an influence. Writer Leopold Atlas became an informer in 1953. His daughter called the act of naming a "golden opportunity sanctioned by the government" (Navasky 1980:363) and added: "I suspected that from my own experiences working within the Hollywood system, people used the blacklist as a way of getting back at other people for things that had nothing to do with politics.... A lot of people who testified did so to get back at people who had gotten jobs away from them." Historian Navasky points out that one motive for naming could have been that it "lessened competition for guild jobs" (1980:346). McGilligan reflected that who was named and who was not "had a lot to do with subtextual or professional rivalries" (McGilligan and Buhle 1997:531). This insight is not followed up with real analysis. To our knowledge, ours is the first systematic analysis of witnesses during the HUAC hearings.

We characterize the informing events as discrediting acts in a network. Discredit is inherently relational, but instead of outflows of deference as in typical network studies, naming represents outflows of discredit that can damage other people's careers and exclude them from consideration for future jobs.

\section{Statistical Analysis}

Our analysis uses three types of data: the list of witnesses and targets named in the HUAC hearings; the career attributes of artists that define the positions in the Hollywood labor market over time; and known affiliations to Communist organizations and events.

\section{Dependent Variable: Naming}

To code the public informing events during the HUAC hearings we used the primary source editions of the Annual Report of the Committee on UnAmerican Activities, which was released yearly to the public. The report listed who testified and who informed on whom. The dependent variable is a dichotomous measure equal to one if an artist was identified as a Communist (named) by a particular witness artist during the hearings, and zero otherwise. We label witnesses who could name names as senders, and the artists who were available to be named receivers. The unit of analysis is each sender-receiver dyad.

We match artists to careers through the screen credits of feature films. Some senders and receivers in the trials did not have the types of film credits we study (see below; for example, they held administrative jobs), so our analysis is conducted on the 106 senders who did. Thirty-one percent of the population of senders $(33 / 106)$ were friendly to the committee and chose to name someone (see also Navasky 1980). The level of participation of testifiers varied. Those in the lowest quartile of naming gave six names or fewer, the middle quartile gave eleven or fewer, and the upper 
quartile named twenty other artists or fewer. We identified a total of 169 receivers who were named.

\section{Independent Variable: Niche Overlap}

We operationalize niche overlap between senders and receivers with the degree of similarity of career features. Ecological niches are multidimensional and we examine the average similarity of the positions of senders and receivers measured from multiple variables linked with their career history. We focus on six aspects that previous research finds to influence the likelihood of obtaining work in film and form the basis of resource competition in the industry: (1) occupation in enacted roles; (2) skill sets and professional identities in film genres; (3) employment credentials by production companies; (4) experience from tenure in the industry; and track records from (5) artistic awards and (6) commercial (box office) success. For example, we expect that an Oscar-nominated actor active in the romance genre would perceive another actor with similar artistic achievement in the same genre as having great overlap in the labor market and as vying for the same kind of projects. Further, we anticipate that an artist had some awareness of other artists' positions through the social comparison process described above. Faulkner (1983:22) noted that the competitive nature of work in Hollywood is such that artists are regularly "talking about who is getting what, who is working with whom and with what effect."

To calculate these variables we use data in the entries compiled by the American Film Institute Catalog of Motion Pictures (AFI), which report cast members, production and distribution companies, release date, length, and genre for all motion pictures produced and released in the United States. Our analysis focuses on the four main creative roles in film-actor, director, writer, and producer (Baker and Faulkner 1991) - in commercial, feature-length pictures until the end of the hearings.

To measure artistic awards and box office success we supplement the AFI entries with data on Academy Award (Oscar) nominations for individual artists (Shale 1993) and data on boxoffice ticketsale grosses from Variety magazine's All-Time Film Rental Champs lists. ${ }^{1}$ Table 1 reports the definitions of the variables, sources and value ranges

For ease of notation the six variables described above are $\mathrm{V}$ and each type of variable is $v$. So, $X_{v, t, i, j}$ represents the values of variable $v$ between artist $i$ and artist $j$ up to year $t$.

The degree of similarity is computed as the average of the six similarities between artists. The independent variable in the analysis, niche overlap, is defined as:

$$
\text { niche_overlap } t_{t, i, j}=\frac{1}{\#\{V\}} \sum_{v \text { in } V}\left(X_{v, t, i, j}\right) \text {. }
$$

The method to compute the values of the variables $V$ differs by type of data. Enacted roles, genres, and production companies are based on categorical data using binary indicators, and the matrices are determined by shared affiliations with nonmutually exclusive roles, genres, or production companies. This is the count of the union of the similar affiliations divided by the total number of affiliations of the 
Table 1: The Variables of Niche Overlap

\begin{tabular}{lcccccc}
\hline Variable and Definition & Data Type & Source & Mean & SD & Min & Max \\
\hline i) Occupation in enacted roles (Baker and & Categ. & AFI & 0.421 & 0.475 & 0 & 1
\end{tabular}

Faulkner 1991)

Similarity indicator of the roles of actor, writer, director, and/or producer in which sender and receiver worked before the trial.

ii) Skill sets and professional identities in film genres (Faulkner 1983; Zuckerman et al. 2003)

$\begin{array}{llllll}\text { Categ. } & \text { AFI } & 0.249 & 0.243 & 0 & 1\end{array}$

Similarity indicator of the genres of the films in which sender and receiver worked before the trial. ${ }^{\dagger}$

iii) Employment credentials by production companies (Faulkner 1983)

Similarity indicator of the companies that produced the films in which sender and receiver worked before the trial.

iv) Industry tenure (Bielby and Bielby 1999)

$\begin{array}{llllll}\text { Contin. } & \text { AFI } & 0.394 & 0.278 & 0.036 & 1\end{array}$

Similarity indicator of the number of years since first film job for sender and receiver before the trial.

v) Artistic track record (Faulkner and Anderson 1987; Baker and Faulkner 1991; Rossman, Esparza, and Bonacich 2010)

Similarity indicator of the individual number of Academy Award nominations for sender and receiver before the trial.

vi) Commercial track record (Faulkner and Anderson 1987; Baker and Faulkner 1991; Cattani Contin. Variety 0.054 0.198 $0 \quad 1$ and Ferriani 2008) (1992)

Similarity indicator of the number of highgrossing films in which sender and receiver worked on before the trial.

Note: AFI= Film entries in American Film Institute catalog

† Genres: Adventure; Allegory; Biography; Children's; Comedy; Crime; Documentary; Drama; Epic; Fantasy; Film noir; Horror; Melodrama; Musical; Musical comedy; Mystery; Romance; Romantic comedy; Satire; Science fiction; Swashbuckler; War; Western. 
sender $i$ :

$$
X_{v, t, u, j}^{\text {categorical }}=\frac{\#\{I \cap J\}}{\#\{I\}},
$$

where $\#\{I \cap J\}$ is the count of affiliations of type $v$ shared by $i$ and $j$ before time $t$ (the cardinality of the intersection set), and $\#\{I\}$ is the count of artist $i$ 's affiliations in $v$ before time $t$ (the cardinality of $i$ 's set of events). These fall within the range $[0,1]$.

Tenure, artistic awards, and box office success are derived from continuous data: total years in the film industry, the number of Academy Award nominations (including wins), or the top-grossing films. These are put into artist-by-artist matrices using the following:

$$
X_{v, t, i, j}^{\text {continuous }}=1-\frac{|I-J|}{\max (I, J)},
$$

where $I$ and $J$ are the counts for artist $i$ or $j$ up to time $t$. The max function takes the larger of the two natural positive numbers and normalizes similarity so it also falls into the range [0,1]. Table A1 in the appendix illustrates two examples for a hypothetical group of artists and how we calculated these matrices for variables based on categorical and continuous data.

Control Variables. First, we control for the artists' levels of Communist involvement. Accounts cite that Communists were personally engaged with each other and partook in social activities, reading groups, and political protests (Ceplair and Englund 1979). When people work together sharing a common ideological or political purpose, this will likely increase solidarity and can mitigate career rivalries and reduce cooperation with the authorities and the odds of naming.

Data about the affiliations of artists to particular Communist organizations come from copies of the original FBI reports (Federal Bureau of Investigation 1947) and the entries in the Red Channels blacklist (American Business Consultants 1950), both published before the 1951 hearings. We counted 168 organizations in these data, including the Communist Party. HUAC relied on these sources as well as other testimony to issue subpoenas in Hollywood. We included a count of each individual's prior Communist organizations and events released before the trials, as reported in the FBI or Red Channels data. We refer to these variables as the Communist Record of the sender and the receiver. Most entries did not report the specific date of affiliation, so we did not change memberships over time.

To control for prior naming, we counted the cumulative number of times the sender and the receiver had been named by other artists up until the sender's testimony. Prior testimony reduces uncertainty but might also reflect weaker antagonism towards a target already outed. Figure 1 illustrates the naming events as outflows in a dynamic network. In the first trial, new people are brought in by the naming event. There tends to be some overlap between the targets, as people are named multiple times. This is revealed visually in some of the clustered areas.

Reciprocity might motivate testifiers to turn on the people who testified against them as an act of retribution. We add a variable for direct reciprocity in the hearings, equal to 1 if receiver $j$ had named sender $i$ previously, and 0 otherwise. Like the previous variables, this incorporates the order of testimonies. 


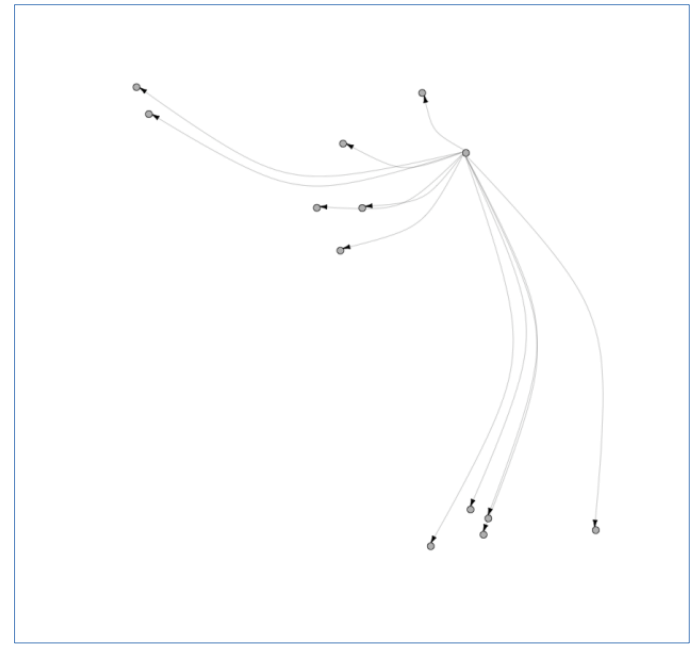

First Trial

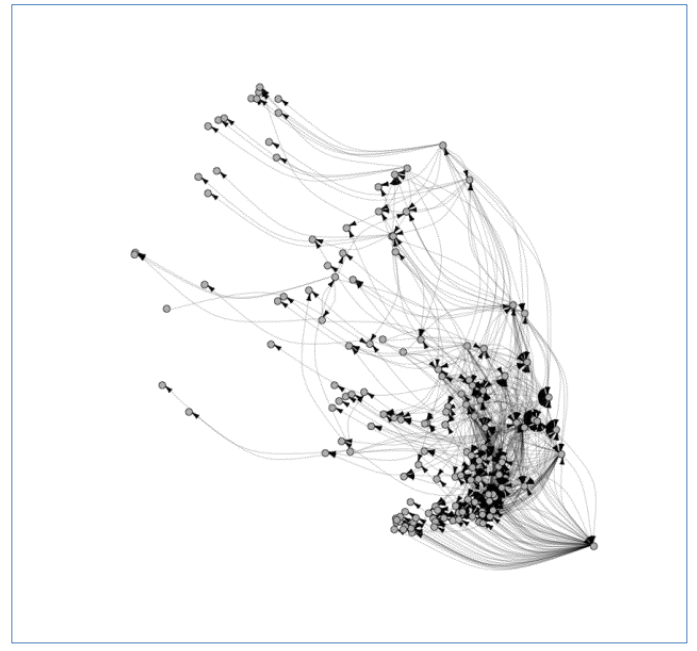

Last Trial

Figure 1: Informing Network in the First and Last Trial

The effect of similarity needs to be separated from the effect of propinquity (Reagans 2011). We control for the process of propinquity by measuring prior ties in film, because productions frequently brought artists in contact with one another, where friendships were sparked. Faulkner (1983:176) defines film projects as events in a two-mode social network, where repeated collaboration could be the result of successful matching in past projects. He argues that shared projects represent a basis for sharing information and experiences. One of the artists he interviewed summarized, "Your friends almost inevitably become the people with whom you work." Further, these collaborations should contribute to how information flows through the network, which affects what competitors know about one another. We count the number of films each pair of artists worked on as an indicator of prior coworker ties.

We calculate additional measures from the collaboration network. Faulkner (1983) argues that artists in more central positions in Hollywood are part of more or bigger projects and have better access to flows of information, gossip, and communication. Degree centrality of each sender and receiver controls for the number of coworker ties. For receivers, centrality can also expand visibility and prominence (Rossman, Esparza, and Bonacich 2010), making such artists bigger targets.

When artists are within a few degrees of separation from each other in the collaboration network, they may have more knowledge of each other-of the people and structure closer to them. Information flows more readily between those nearby in the network, and social comparison ought to result in more opportunities to identify similar competitors and scrutinize their affiliations and relationships. Therefore, informing should occur closer in the network. We control for network distance using the shortest path between prior coworkers (Floyd 1962).

Informing choices might result from other patterns of prior collaboration and naming. The ties in the naming network $\mathrm{N}$ at time $t$ can reveal antagonism, while 


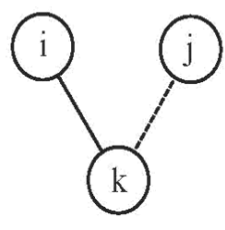

$\mathrm{CN}$

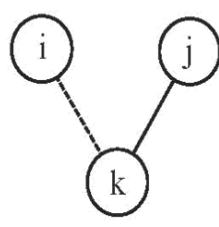

$\mathrm{NC}$

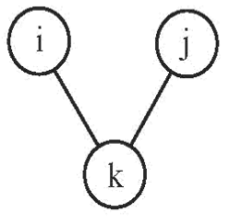

$\mathrm{CC}$

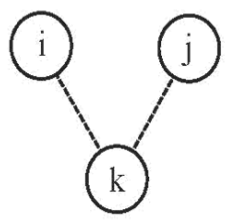

$\mathrm{NN}$

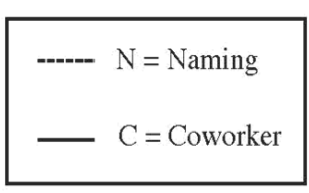

Figure 2: Types of Triadic Relationships Analyzed

the collaboration network $C$ at the time can reveal mutualism. These triadic relations bear a resemblance to the triads in balance theory (Cartwright and Harary 1956). Using relational algebra, these matrices are simply multiplied to produce counts of the following events, depicted in Figure 2: CN, NC, CC, and NN. These triadic relationships incorporate both of these types of ties.

For example, the cells in the matrix product $\mathrm{CN}$ are counts of the number of $i$ 's coworkers who informed on the receiver $j$ before the testifier has the opportunity. Since each coworker can name the potential target one time, the count is the number of coworkers of $i$ who have informed on $j$ before $i$ 's trial. Another example is the CC measure, which indicates connections of length two in the collaboration network. One can anticipate that information diffusion in the local network will increase awareness of informing through people in close positions. To control for time trends, we include a calendar year variable. Table 2 contains the summary statistics.

\section{Estimation}

We estimate a logit of the odds that each sender will name any other artist in the industry using a link prediction model from social network analysis. The statistical model allows each sender to inform on a receiver; the potential receivers include those who worked between 1945 and the year prior to each witness' testimony, and the senders are the artists in the sample who testified. ${ }^{2}$

We use a multi-level logit with crossed random effects to control for nonindependence of observations and unobserved, time-invariant individual features of senders and receivers, such as gender and cultural background (van Duijn, Snijders, and Zijlstra 2004; Rabe-Hesketh and Skrondal 2008). We prefer this estimation approach to alternatives such as exponential random graph models (ERGM) because it handles very large networks that change over time, a requirement given the size of the Hollywood collaboration network, but a limitation of ERGMs at the time of analysis.

HUAC investigators approved witnesses before they testified. This can lead to selection bias, and we estimate our main model using a two-stage design. While this approach does not eliminate all possible bias, we think it reduces it significantly. In the first stage, we estimate a probit model of the likelihood of being called to testify and use data on all artists who worked in feature films during the study period. We took the inverse Mills ratio of the estimated coefficients and included it in the dyadic models of informing to correct for the sampling bias for the sender. 
Table 2: Summary Statistics for Analysis of Informing during the HUAC Hearings

\begin{tabular}{lrr}
\hline Variable & Mean & \multicolumn{1}{c}{ SD } \\
\hline (1) Niche Overlap & 0.210 & 0.143 \\
(2) Communist Record Sender & 2.311 & 5.408 \\
(3) Communist Record Receiver & 0.036 & 0.679 \\
(4) Prior Coworker Ties & 0.370 & 0.321 \\
(5) Direct Reciprocity & 0.00002 & 0.004 \\
(6) Prior Naming Sender & 0.750 & 1.281 \\
(7) Prior Naming Receiver & 0.012 & 0.242 \\
(8) Network Centrality Sender & 552.215 & 595.378 \\
(9) Network Centrality Receiver & 318.604 & 517.451 \\
(10) Network Distance & 1906.962 & 7256.553 \\
(11) Triadic Relationships: CN & 0.001 & 0.035 \\
(12) Triadic Relationships: NC & 0.032 & 0.181 \\
(13) Triadic Relationships: CC & 3.690 & 4.354 \\
(14) Triadic Relationships: NN & 0.003 & 0.152 \\
(15) Year (1950=0) & 2.138 & 1.288 \\
\hline
\end{tabular}

The probit regressions are reported in Table A2 in the appendix. In the second stage, we estimated the model of informing with a logistic regression using a mixed-effect procedure.

\section{Results}

Table 3 contains the results of the multi-level logit regression models. Model 3.1 includes the niche overlap covariate without any statistical controls and shows a positive and statistically significant coefficient. The total fit of the model improves significantly when overlap is added to a model including only a constant term $\left(X^{2}=803.75, p<0.001\right)$. This provides preliminary support for the hypothesis. A likelihood ratio test that compares this model with a model without random-effect corrections indicates that the between-cluster variance is significant $\left(X^{2}=482.19\right.$, $p<0.001)$, suggesting that a multi-level model of the kind we estimated is required (Rabe-Hesketh and Skrondal 2008). Model 3.2 presents the full specification. The niche overlap coefficient continues to have a positive and significant sign. Based on an evaluation of the odds ratios, a standard deviation (0.142) increase in niche overlap above zero increases the estimated odds of naming by a factor of 4.09 (exp. $9.924 \times 0.142$ ). To summarize, the odds of discredit increase significantly with greater niche overlap between artists, holding other variables constant.

Model 3.2 reveals additional aspects of the HUAC testimonies that historical accounts have speculated about but not analyzed. In retrospective interviews, some artists claimed to reduce the amount of damage to others by naming people who had already been named in prior trials. For example, writer Leo Townsend said "I didn't name anyone that hadn't been named." The negative coefficient on Prior Naming Receiver indicates instead that informers tended to name new people. In 
Table 3: Maximum-Likelihood Estimates of Informing during the HUAC Hearings (Cross Random-Effects Logistic Regression)

\begin{tabular}{|c|c|c|}
\hline Variable & Model 3.1 & Model 3.2 \\
\hline Constant & $\begin{array}{r}-16.152^{*} \\
(0.482)\end{array}$ & $\begin{array}{r}-6.921^{\dagger} \\
(3.638)\end{array}$ \\
\hline Niche Overlap & $\begin{array}{r}9.476^{*} \\
(0.352)\end{array}$ & $\begin{array}{r}9.924^{*} \\
(1.467)\end{array}$ \\
\hline Communist Record Sender & & $\begin{array}{r}-0.844^{*} \\
(0.275)\end{array}$ \\
\hline Communist Record Receiver & & $\begin{array}{r}-0.097^{*} \\
(0.028)\end{array}$ \\
\hline Prior Coworker Ties & & $\begin{array}{r}-0.399^{*} \\
(0.200)\end{array}$ \\
\hline Network Centrality Sender & & $\begin{array}{r}-0.007^{*} \\
(0.002)\end{array}$ \\
\hline Network Centrality Receiver & & $\begin{array}{c}-0.0004 \\
(0.0004)\end{array}$ \\
\hline Network Distance & & $\begin{array}{r}9.88 \mathrm{E}-06 \\
(0.0001)\end{array}$ \\
\hline Direct Reciprocity & & $\begin{array}{c}4.133^{*} \\
(0.664)\end{array}$ \\
\hline Prior Naming Sender & & $\begin{array}{c}-0.507 \\
(0.919)\end{array}$ \\
\hline Prior Naming Receiver & & $\begin{array}{r}-0.114^{*} \\
(0.052)\end{array}$ \\
\hline Triadic Relationships: CN & & $\begin{array}{l}13.653^{*} \\
(0.514)\end{array}$ \\
\hline Triadic Relationships: NC & & $\begin{array}{c}-0.062 \\
(0.342)\end{array}$ \\
\hline Triadic Relationships: CC & & $\begin{array}{r}-0.166^{*} \\
(0.069)\end{array}$ \\
\hline Triadic Relationships: NN & & $\begin{array}{r}0.165^{*} \\
(0.047)\end{array}$ \\
\hline Year & & $\begin{array}{c}0.195 \\
(0.638)\end{array}$ \\
\hline Selection Bias & & $\begin{array}{r}-3.445^{*} \\
(1.312)\end{array}$ \\
\hline$\psi_{1}$ (receiver) & $\begin{array}{l}0.001 \\
(0.0001)\end{array}$ & $\begin{array}{c}0.001 \\
(1.51 \mathrm{E}-05)\end{array}$ \\
\hline$\psi_{2}$ (sender) & $\begin{array}{c}0.0004 \\
(0.0001)\end{array}$ & $\begin{array}{r}0.0004 \\
(2.94 \mathrm{E}-05)\end{array}$ \\
\hline Log-likelihood & $-3,702.347$ & -594.08 \\
\hline
\end{tabular}

Note: $* p<0.05 ;+p<0.10$ (two-tailed). Standard errors in parentheses. $\mathrm{N}=2,130,130$. 
fact, our data indicate that Townsend was the first to inform on six writers. This effect is compatible with the niche overlap explanation that testifiers would attempt to push artists out of the market, and since each testifier might have a somewhat distinct set of potential competitors, these would be new people. Naming new targets would also expand the reach of the HUAC investigations.

Some artists were more candid about the reasons for giving names. Writer Roland Kibbee admitted that he went before the committee and named those who had given his name (Navasky 1980). The reciprocity variable reveals that senders are likely to inform on those who named them in previous testimony, consistent with a retaliation motive.

Other structural relations are indicated by the coefficients of the triadic variables. In particular, senders show higher odds of naming a receiver when a third party formed a naming tie with both of them earlier (the NN triad variable is statistically significant). This suggests the presence of a latent clustered structure of Communist linkages not observable in the FBI and other blacklisting data.

The main model reveals that the tendency to inform can be mitigated by repeated collaborations between artists. As expected, the odds of naming decrease with more coworker ties. Model 3.2 also includes the inverse Mills ratio to address the sender selection bias. Although interpreting the selection term is disputable (Dolton and Makepeace 1987), it seems that the odds of naming decrease with factors that increase the probability of being targeted by HUAC (i.e., level of Communist record). Details of the first-stage estimation are in Table A2 in the appendix.

\section{Additional analyses}

We test the robustness of the results in Table 4. Kilduff and Brass (2010) argue that rivalry does not require direct communication between actors, and our main analysis assumes that both close and distant social comparison is sufficient. In model 4.1, we examine whether the competitive pressure linked to niche overlap holds when senders and receivers did not work together in films at all. We reestimate the main specification excluding all dyads with prior coworker ties and find patterns similar to those reported in model 3.2.

Artists may also develop ties with one another in Communist organizations, and in model 4.2 we replicate the previous specification without coworkers and artists affiliated with Communist organizations. The niche overlap measure continues to show a positive and statistically significant effect. The estimates of this model suggest that the degree of similarity of positions within the job market is linked to the odds of informing on others above and beyond ideology and social ties. Further, the inclusion of random effects on senders isolates the niche overlap effects from those of individual-level characteristics, suggesting that informers were not necessarily just mean-spirited or more likely to turn over names.

Because niche overlap measures the average of the artist-by-artist similarities, we assume that each artist only compared her own career to the receiver's. Yet artists could perceive a web of relationships through the social structure created by third parties. In model 4.3 we measure niche overlap using the correlation coefficient on the six variables defined in equations (2) and (3), stacking the matrices 
Table 4: Maximum-Likelihood Estimates of Informing during the HUAC Hearings - Robustness Tests (Cross Random-Effects Logistic Regression)

\begin{tabular}{|c|c|c|c|}
\hline & $\begin{array}{c}\text { Model } 4.1 \\
\text { Excluding } \\
\text { Coworker Ties }\end{array}$ & $\begin{array}{l}\text { Model } 4.2 \\
\text { Excl. Coworker Ties } \\
\text { \& Communist Affil. }\end{array}$ & $\begin{array}{c}\text { Model } 4.3 \\
\text { Niche Overlap as } \\
\text { Correlation Coeff. }\end{array}$ \\
\hline Constant & $\begin{array}{r}-6.221 \\
(4.434)\end{array}$ & $\begin{array}{r}-28.139^{*} \\
(11.576)\end{array}$ & $\begin{array}{r}-6.921^{\dagger} \\
(3.638)\end{array}$ \\
\hline Niche Overlap & $\begin{array}{c}8.373^{*} \\
(1.531)\end{array}$ & $\begin{array}{r}7.069^{*} \\
(2.960)\end{array}$ & $\begin{array}{r}6.587^{*} \\
(0.999)\end{array}$ \\
\hline Communist Record Sender & $\begin{array}{r}-0.924^{*} \\
(0.291)\end{array}$ & & $\begin{array}{r}-0.803^{*} \\
(0.275)\end{array}$ \\
\hline Communist Record Receiver & $\begin{array}{r}-0.117^{*} \\
(0.034)\end{array}$ & & $\begin{array}{r}-0.083^{*} \\
(0.027)\end{array}$ \\
\hline Prior Coworker Ties & & & $\begin{array}{r}-0.222^{*} \\
(0.106)\end{array}$ \\
\hline Network Centrality Sender & $\begin{array}{r}-0.008^{*} \\
(0.001)\end{array}$ & $\begin{array}{r}-0.013^{*} \\
(0.003)\end{array}$ & $\begin{array}{r}-0.008^{*} \\
(0.002)\end{array}$ \\
\hline Network Centrality Receiver & $\begin{array}{c}-0.0003 \\
(0.0004)\end{array}$ & $\begin{array}{c}0.001 \\
(0.001)\end{array}$ & $\begin{array}{r}-0.001^{+} \\
(0.000)\end{array}$ \\
\hline Network Distance & $\begin{array}{r}2.2 \mathrm{E}-05 \\
(8.7 \mathrm{E}-05)\end{array}$ & $\begin{array}{r}-1.55 \mathrm{E}-04 \\
(4.05 \mathrm{E}-04)\end{array}$ & $\begin{array}{r}2.33 \mathrm{E}-05 \\
(8.10 \mathrm{E}-05)\end{array}$ \\
\hline Direct Reciprocity & $\begin{array}{r}3.850^{*} \\
(0.812)\end{array}$ & $\begin{array}{c}5.815^{*} \\
(1.240)\end{array}$ & $\begin{array}{r}4.097^{*} \\
(0.621)\end{array}$ \\
\hline Prior Naming Sender & $\begin{array}{c}-0.535 \\
(1.184)\end{array}$ & $\begin{array}{r}-3.484^{*} \\
(1.684)\end{array}$ & $\begin{array}{c}-0.541 \\
(0.839)\end{array}$ \\
\hline Prior Naming Receiver & $\begin{array}{c}-0.077 \\
(0.061)\end{array}$ & $\begin{array}{c}0.441^{*} \\
(0.135)\end{array}$ & $\begin{array}{r}-0.145^{*} \\
(0.052)\end{array}$ \\
\hline Triadic Relationships: CN & $\begin{array}{l}15.305^{*} \\
(0.764)\end{array}$ & $\begin{array}{l}19.064^{*} \\
(1.808)\end{array}$ & $\begin{array}{l}13.434^{*} \\
(0.509)\end{array}$ \\
\hline Triadic Relationships: NC & $\begin{array}{c}0.526 \\
(0.404)\end{array}$ & $\begin{array}{r}-0.301 \\
(0.834)\end{array}$ & $\begin{array}{r}-0.112^{*} \\
(0.345)\end{array}$ \\
\hline Triadic Relationships: CC & $\begin{array}{r}-0.289^{*} \\
(0.077)\end{array}$ & $\begin{array}{r}-0.271^{*} \\
(0.125)\end{array}$ & $\begin{array}{r}-0.031 \\
(0.061)\end{array}$ \\
\hline Triadic Relationships: NN & $\begin{array}{c}0.128^{*} \\
(0.052)\end{array}$ & $\begin{array}{c}0.101 \\
(0.118)\end{array}$ & $\begin{array}{c}0.171^{*} \\
(0.046)\end{array}$ \\
\hline Year & $\begin{array}{c}0.090 \\
(0.839)\end{array}$ & $\begin{array}{r}-4.221^{*} \\
(1.189)\end{array}$ & $\begin{array}{c}0.249 \\
(0.614)\end{array}$ \\
\hline Selection Bias & $\begin{array}{r}-3.813^{*} \\
(1.586)\end{array}$ & $\begin{array}{c}3.174 \\
(3.948)\end{array}$ & $\begin{array}{r}-3.306^{*} \\
(1.241)\end{array}$ \\
\hline$\psi_{1}$ (receiver) & $\begin{array}{c}0.001 \\
(1.91 \mathrm{E}-05)\end{array}$ & $\begin{array}{c}0.002 \\
(1.98 \mathrm{E}-05)\end{array}$ & $\begin{array}{c}0.001 \\
(0.0001)\end{array}$ \\
\hline$\psi_{2}$ (sender) & $\begin{array}{r}0.0004 \\
(3.54 \mathrm{E}-05)\end{array}$ & $\begin{array}{c}0.001 \\
(3.46 \mathrm{E}-05)\end{array}$ & $\begin{array}{r}0.0004 \\
(1.51 \mathrm{E}-05)\end{array}$ \\
\hline Log-likelihood & -489.361 & -244.369 & -593.942 \\
\hline $\mathrm{N}$ & 2,071,293 & $1,363,584$ & $2,130,130$ \\
\hline
\end{tabular}

Note: $* p<0.05 ;+p<0.10$ (two-tailed). Standard errors in parentheses. 
Table 5: Maximum-Likelihood Estimates of Informing during the HUAC Hearings - Robustness Tests (Cross Random-Effects Logistic Regression)

Niche Overlap Variables

\begin{tabular}{lc}
\hline RGOBP & $8.729^{*}$
\end{tabular}

(1.178)

$\begin{array}{ll}\text { TGOBP } & 6.726^{*}\end{array}$

$6.600^{*}$

RTGBP $\quad 7.158^{*}$

$\begin{array}{ll}\text { RTGOB } & 8.437^{*}\end{array}$

$-9.028$

Note: $\mathrm{B}=$ Commercial Success; $\mathrm{G}=$ Genre; $\mathrm{O}=$ Academy Awards; $\mathrm{P}=$ Production Company; $\mathrm{R}=$ Role; $\mathrm{T}$ $=$ Tenure. The estimates are obtained from model specifications including the same control variables as in Model 4.2.

$* p<0.05$ (two-tailed). Standard errors in parentheses.

and correlating each artist's position with every other position, which accounts for indirect connections between each pair of artists via third parties. We find that the odds of informing also increase with greater niche overlap when we use the correlation coefficient.

Features directly and indirectly related to performance can be relevant for social comparison. The niche overlap variable groups together a number of factors that measure performance in different ways. These factors include economic success and prestige (box office success and Academy awards), but also variables defining professional identities (e.g., film genres and roles). We test whether the effect of niche overlap is sensitive to each individual factor by separately re-estimating our main model specification excluding each one of the six niche variable. Table 5 summarizes these estimates and finds that while the magnitude of the coefficient of the niche overlap variable varies, its statistical significance does not depend solely on any particular variable.

The main model 3.2 allows senders to name any artist in Hollywood and has a very large number of observations. In analyses not shown for the sake of brevity, we consider alternative risk sets and models. In the first, receivers must have Communist records before the trials. In this smaller risk set $(\mathrm{N}=16,974)$, niche overlap remains significant and points in the same direction $(\beta=8.845$; S.E. $=1.845$, $p<0.01)$. The main result of niche overlap $(\beta=2.176$; S.E. $=0.531, p<0.01)$ also holds when we account for the sender and receiver having the same gender, which we could only code for the smaller sample but not the entire risk set of receivers. In additional analyses we test whether the effect of niche overlap might be biased by a collider. We do this by considering as receivers only the artists with 
Communist records before any of the hearings (and not those named during). The niche overlap effect remains positive and statistically significant. Another potential source of spuriousness is the interaction among Communist-leaning artists outside of film projects, in party meetings or committees, but the niche overlap effect remains virtually unchanged when we replace the Communist records of senders and receivers with their overlap in Communist organizations and events. In other analyses, the niche overlap has similar performance to alternative measures of niche overlap based on Euclidean $(\beta=-0.092 ;$ S.E. $=0.011, p<0.01)$ and cosine distance $(\beta=-9.945 ;$ S.E. $=2.194, p<0.01)$.

\section{Discussion}

Social scientists studying negative outcomes tend to focus on groups instead of individuals, and they show that collective conflict involves an element of similarity. Violent protests are more likely to erupt when immigrant groups share a pool of lowwage labor in the same region (Olzak 1992). Urban gangs commit murders against one another at higher rates when they operate on the same economic and cultural turf (Papachristos 2009). Vengeances are calibrated in such a way to demonstrate that the cohesiveness of the avenger group is comparable to the cohesiveness of the original offenders (Gould 2000). Political groups with similar levels of wealth and prestige engage in the most intense struggles for resources, such as those between the Medicean party and the oligarchs in 1400's Florence (Padgett and Ansell 1993).

Simmel (1904:514) observed that commonalities, not simply differences, explain individual negative reactions including hate, envy, and the desire to defeat others: "An enmity must excite consciousness the more deeply and energetically the greater the similarity between the parties among whom it originates." While a large body of sociological research has examined how similarity increases communication and emotional attachment in positive interpersonal connections, there is less attention to its function in antagonistic relations. This is surprising, for at least three reasons. First, negative ties in the form of conflict between individuals, groups, movements, and organizations are known to exist in most social systems. Second, people exhibit a systematic bias in the perception of negative stimuli so that negative emotions, events, and relationships tend to be more impactful, stable, and long-lasting than their positive counterparts (Rozin and Royzman 2001). Third, positive and negative relations are sometimes closely interrelated in counterintuitive ways. Granovetter (1985) argues that the production of trust does not prevent opportunism, malfeasance, and disorder. On the contrary, opportunities for unscrupulous behavior increase when individuals are more closely associated with one another.

The findings of this article suggest that structural similarity is significantly linked to discredit. This challenges the common assumption that similarity only encourages trust, positive affect, and deference in markets, and that agents in similar positions have weaker incentives for anti-social behavior. The integration of ecological and network perspectives provides an account for why similarity between market agents does not necessarily mitigate self-serving actions. Within webs of affiliation, market agents compare and evaluate the structure of connections to other players and identify potential targets of actions that could secure favorable 
returns. An ideal analysis of such ecological networks should account for the social comparison process as well as relevant socio-structural similarities, such as market performance, status attainment, and role identity.

The evidence reveals that increased similarity of market positions does not necessarily lead to homophily. The discredit associated with similarity can be strong enough to undercut alliances implied from having some shared ideological affiliations (here, membership in Communist organizations). Yet the odds of informing decrease with greater propinquity, as measured by the number prior collaborations. These opposing patterns remind us that homophily and propinquity represent distinct processes. Propinquity is more associated with perceptions of a space that can accommodate multiple agents simultaneously, whereas the similarity of market positions is more associated with perceptions of niche overlap and competition.

These findings can also speak to the assumption often made by researchers in other theoretical perspectives such as social identity theory (Tajfel and Turner 1986) and similarity-attraction theory (Byrne 1971). In these perspectives, similarity among group members increases their reciprocal attraction and leads to in-group favoritism and out-group antagonism. What is often neglected is that competition can take place within, as well as between, groups. The members of a nominal group might be relatively more preferred, trusted, and likely to share opportunities, but this does not mean that competition within the group disappears.

Group experiments conducted by Karp et al. (1993) find that when participants in a minimal group study are told that their outcomes are independent of the decisions of others, evidence for in-group bias disappears. They argue that the expectation of consequential benefits from the group strongly motivates favoring the in-group, and removing that expectation causes people to act in a more selfinterested fashion.

The HUAC case may seem exceptional in certain respects. Yet the boundary conditions we describe suggest that discredit becomes opportune in other situations where its cost is lowered. Sociologists (Berger, Berger, and Kellner 1973) and economists (Shleifer 2004) argue that drifting norms allow negative behaviors to diffuse in markets, whereby behaviors that were once considered unethical-for example, disproportionate executive pay-are enacted with limited or no liability. Aspects of certain modern markets can lower the risk of retribution, such as online systems where transactions and attacks are made anonymously. In such cases, actions can be taken to gainfully edge out competitors.

The findings of this article can apply to other institutional settings. In particular, niche overlap might explain an unusual outcome in studies of intra-organizational whistle-blowing. Typically, researchers argue that employees who work near wrongdoers would be less likely to report wrongdoing, with one reason being that a nearby coworker is more likely to be a friend, and blowing the whistle would risk a positive relationship. Nevertheless, a recent meta-analysis of whistle-blowing studies (Mesmer-Magnus and Viswesvara 2005) finds that working near the wrongdoer has a positive correlation with the intent to report. Proximity does not only imply opportunities for contact; it can often indicate similarity of organizational roles. Given the findings we report about career similarity and discredit, the unexpected 
empirical result could be explained by niche similarity having a stronger effect than propinquity.

\section{Notes}

1 We used the list compiled by Lawrence Cohn in the Variety issue of February 24, 1992.

2 To allow for a large window before the HUAC hearings, we reconstructed each artist's career history from 1927 onwards. This date coincides with the transition of the film industry to sound, which transformed industrial practices and careers in Hollywood. This start date also predates the periods of retrospective contention during the HUAC hearings, namely the Popular Front period (1934-1939) and the U.S. mobilization for World War II.

\section{References}

Aldrich, Howard A. 1999. Organizations Evolving. Thousand Oaks, CA: Sage.

American Business Consultants. 1950. Red Channels: The Report of Communist Influence in Radio and Television. New York.

American Film Institute. 1993-1999. The American Film Institute Catalog of Motion Pictures Produced in the United States: Feature Films, 1921-1930, 1931-1940, 1941-1950, 1951-1960. Berkeley: University of California Press.

Baker, Wayne and Robert R. Faulkner. 1991 "Role as Resource in the Hollywood Film Industry." American Journal of Sociology 97:279-309. http://dx. doi .org/10. 1086/229780.

Baker, Wayne and Robert R. Faulkner. 2003. "Diffusion of Fraud: Intermediate Economic Crime and Investor Dynamics." Criminology 41:1601-1634. http://dx.doi.org/10. 1111/j.1745-9125.2003.tb01017.x.

Berger, Peter, Brigitte Berger, and Hansfried Kellner. 1973. The Homeless Mind: Modernization and Consciousness. New York: Random House.

Bielby, William T. and Denise D. Bielby. 1999. “Organizational Mediation of Project-Based Labor Markets: Talent Agencies and the Careers of Screenwriters." American Sociological Review 64:64-85. http://dx.doi .org/10.2307/2657278.

Burt, Ronald S. 1982. Toward a Structural Theory of Action: Network Models of Social Structure, Perception, and Action. New York: Academic Press. http://dx.doi .org/10.1016/ b978-0-12-147150-7.50014-4.

Burt, Ronald S. 1987. "Social Contagion and Innovation: Cohesion versus Structural Equivalence". American Journal of Sociology 92:1287-1335. http://dx . doi .org/10 . 1086/228667.

Burt, Ronald S. 1992. Structural Holes. The Social Structure of Competition. Cambridge: Harvard University Press.

Burt, Ronald S. and Ilan Talmud. 1993. "Market Niche.” Social Networks 15:133-149. http: //dx.doi.org/10.1016/0378-8733(93)90002-3.

Byrne, Donn. 1971. The Attraction Paradigm. New York: Academic Press.

Cartwright, Dorwin and Frank Harary. 1956. "Structural Balance: A Generalization of Heider's Theory." Psychological Review 63:277-293. http://dx. doi .org/10. 1037/h0046049.

Cattani, Gino and Simone Ferriani. 2008. "A Core/Periphery Perspective on Individual Creative Performance: Social Networks and Cinematic Achievements in the Hollywood 
Film Industry." Organization Science 19:824-844. http://dx.doi.org/10.1287/orsc. 1070.0350 .

Ceplair, Larry and S. Englund. 1979. The Inquisition in Hollywood: Politics in the Film Community, 1930-60. Champaign: University of Illinois Press.

Cogley, John. 1956. Report on Blacklisting Vol. I Movies. New York: Fund for the Republic.

Dolton, P. J. and G H. Makepeace. 1987. "Marital Status, Child Rearing and Earnings Differentials in the Graduate Labour Market." Economic Journal 97:897-922. http://dx . doi .org/10.2307/2233079.

Faulkner, Robert R. 1983. Music on Demand. Composers and Careers in the Hollywood Film Industry. New Brunswick, NJ: Transaction Books.

Faulkner, Robert R. and Andy B. Anderson. 1987. "Short-Term Projects and Emergent Careers: Evidence from Hollywood." American Journal of Sociology 92:879-909. http: //dx.doi.org/10.1086/228586.

Federal Bureau of Investigation. 1947. Communist Infiltration-Motion Picture Industry, Document number 100-138754, Serial 250, Part 5 of 15.

Floyd, Robert W. 1962. "Algorithm 97 (Shortest Path)." Communications of the ACM 5:345. http://dx.doi.org/10.1145/367766.368168.

Garcia, Stephen M. Hyunjin Song, and Abraham Tesser. 2010. “Tainted Recommendations: The Social Comparison Bias." Organizational Behavior and Human Decision Processes 113:97101. http://dx.doi.org/10.1016/j.obhdp.2010.06.002.

Garcia, Stephen M., Avishalom Tor, and Richard Gonzalez. 2006. "Ranks and Rivals: A Theory of Competition." Personality and Social Psychology Bulletin 32:970-982. http: //dx.doi.org/10.1177/0146167206287640.

Garcia, Stephen M., Avishalom Tor, and Tyrone M. Schiff. 2013. “The Psychology of Competition: A Social Comparison Perspective." Perspectives on Psychological Science 8:634-650. http://dx.doi.org/10.1177/1745691613504114.

Gilbert, Daniel T., R. Brian Giesler, and Kathryn A. Morris. 1995. "When Comparisons Arise." Journal of Personality and Social Psychology 69:227-236. http://dx.doi .org/10 . 1037/0022-3514.69.2.227.

Gould, Roger V. 2000. "Revenge as Sanction and Solidarity Display: An Analysis of Vendettas in Nineteenth-Century Corsica." American Sociological Review 65:682-704. http://dx. doi .org/10.2307/2657542.

Granovetter, Mark. 1985. "Economic Action and Social Structure: The Problem of Embeddedness." American Journal of Sociology 91:481-510. http://dx . doi . org/10.1086/228311.

Hannan, Michael T. and John Freeman. 1977. "The Population Ecology of Organizations." American Journal of Sociology 82:929-64. http: //dx . doi . org/10.1086/226424.

Hannan, Michael T., Laszlo Pólos, and Glenn R. Carroll. 2007. Logics of Organization Theory: Audiences, Code, and Ecologies. Princeton: Princeton University Press.

Hawley, Amos H. 1950. Human Ecology. New York: Ronald Press.

Karp, David, Nobuhito Jin, Toshio Yamagishi, and Hiromi Shinotsuka. 1993. "Raising the Minimum in the Minimal Group Paradigm." Japanese Journal of Experimental Psychology 32:231-240. http://dx.doi.org/10.2130/jjesp.32.231.

Kilduff, Gavin, Adam G. Galinsky, Edoardo Gallo, and James J. Reade. 2012. "Whatever It Takes: Rivalry and Unethical Behavior." Paper presented at the 25th Annual IACM Conference. http://dx.doi.org/10.2139/ssrn. 2084845. 
Kilduff, Martin and Daniel J. Brass. 2010. “Organizational Social Network Research: Core Ideas and Key Debates." Academy of Management Annals 4:317-357. http: //dx. doi .org/ 10.1080/19416520.2010.494827.

Lazarsfeld Paul F. and Robert K. Merton. 1954. “Friendship as a Social Process: A Substantive and Methodological Analysis." Pp. 18-66 in Freedom and Control in Modern Society, edited by Morroe Berger, Theodore Abel, and Charles H. Page. New York: Van Nostrand.

McGilligan, Patrick and Paul Buhle. 1997. Tender Comrades: A Backstory of the Hollywood Blacklist. New York: St. Martin's Griffin.

McPherson, J. Miller. 1983. "An Ecology of Affiliation." American Sociological Review 48:51935. http://dx.doi.org/10.2307/2117719.

Mesmer-Magnus Jessica R. and Chockalingam Viswesvaran. 2005. “Whistleblowing in Organizations: An Examination of Correlates of Whistleblowing Intentions, Actions, and Retaliation." Journal of Business Ethics 62:277-297. http://dx.doi .org/10.1007/ s10551-005-0849-1.

Navasky, Victor S. 1980. Naming Names. New York: Viking.

Olzak, Susan. 1992. The Dynamics of Ethnic Competition and Conflict. Stanford: Stanford University Press.

Padgett, John and Christopher K. Ansell. 1993. "Robust Action and the Rise of the Medici, 1400-1434." American Journal of Sociology 98:1259-1319. http://dx . doi .org/10 . 1086/ 230190.

Papachristos, Andrew V. 2009. "Murder by Structure: Dominance Relations and The Social Structure of Gang Homicide." American Journal of Sociology 115:74-128. http://dx. doi . org/10.1086/597791.

Park, Robert, Ernest W. Burgess, and Roderick D. McKenzie. 1925. The City. Chicago: University of Chicago Press.

Podolny, Joel M., Toby E. Stuart, and Michael T. Hannan. 1996. “Networks, Knowledge and Niches: Competition in the Worldwide Semiconductor Industry, 1984-1991." American Journal of Sociology 102:659-689. http://dx. doi.org/10.1086/230994.

Pontikes, Elizabeth G., Giacomo Negro, and Hayagreeva Rao. 2010. “Stained Red: A Study of Stigma by Association to Blacklisted Artists during the "Red Scare" in Hollywood, 1945 to 1960." American Sociological Review 75:456-478. http://dx.doi.org/10.1177/ 0003122410368929.

Rabe-Hesketh, Sophia and Anders Skrondal. 2008. Multilevel and Longitudinal Modeling Using Stata. College Station, TX: Stata Press.

Reagans Ray E 2011 "Close Encounters: Analyzing How Social Similarity and Propinquity Contribute to Strong Network Connections." Organization Science 22: 835-849. http: //dx.doi.org/10.1287/orsc.1100.0587.

Rossman, Gabriel, Nicole Esparza, and Philip Bonacich. 2010. "I'd Like to Thank the Academy, Team Spillovers, and Network Centrality." American Sociological Review 78:3151. http://dx.doi.org/10.1177/0003122409359164.

Rozin, Paul and Edward B. Royzman. 2001. "Negativity Bias, Negativity Dominance, and Contagion." Personality and Social Psychology Review 5:296-320. http://dx.doi .org/10. 1207/S15327957PSPR0504_2.

Sampson, Samuel F. 1968. "A Novitiate in a Period of Change: An Experimental and Case Study of Social Relationships." Unpublished Ph.D. Dissertation, Cornell University.

Shale, Richard. 1993. The Academy Awards Index: The Complete Categorical and Chronological Record. Westport, CT: Greenwood Press. 
Shleifer, Andrei. 2004. "Does Competition Destroy Ethical Behavior?" American Economic Review 94:414-418. http://dx.doi.org/10.1257/0002828041301498.

Sørensen, Jesper B. 1999. “The Ecology of Organizational Demography: Managerial Tenure Distributions and Organizational Competition." Industrial and Corporate Change 8:713-744. http://dx.doi.org/10.1093/icc/8.4.713.

Tajfel, Henri and John C. Turner. 1986. "The Social Identity Theory of Intergroup Behavior." Pp. 7-24 in Psychology of Intergroup Relations, edited by Stephen Worchel and William G. Austin. Chicago: Nelson-Hall.

U.S. Congress, House Committee on Un-American Activities. 1951-1955. Annual Report. Washington: U.S. Government Printing Office.

van Duijn, Marjtjie A. J., Tom A. B. Snijders, and Bonne J. H. Zijlstra. 2004. "p2: a Random Effects Model with Covariates for Directed Graphs." Statistica Neerlandica 58:234-254. http://dx.doi.org/10.1046/j.0039-0402.2003.00258.x.

White, Harrison C. 1981. "Where Do Markets Come From?" American Journal of Sociology 87:517-547.

White, Harrison C. 2008. Identity and Control: How Social Formations Emerge. Princeton: Princeton University Press.

Zuckerman, Ezra W., Tai-Young Kim, Kalinda Ukanwa, and James von Rittman. 2003. "Robust Identities or Non-Entities? Typecasting in the Feature Film Labor Market." American Journal of Sociology 108:1018-1074. http://dx. doi .org/10.1086/377518.

Acknowledgements: Emily Bianchi, Michael Hannan, Balázs Kovács, Wes Longhofer, John Levi Martin, James Moody, Jill Perry-Smith, Elizabeth Pontikes, Chris Rider, Peter Roberts, Gabriel Rossman, Jesper Sørensen, Olav Sorenson, Anand Swaminathan, Jim Wade, Dave Waguespack, and seminar participants at Stanford University, Oxford University, and Yale University offered helpful critiques on the current or previous versions of the manuscript. We thank Hayagreeva Rao for his contributions to earlier stages of the study. Olgert Denas provided research assistance.

Giacomo Negro: Emory University. E-mail: giacomo.negro@emory.edu.

Sasha Goodman: Northeastern University and Harvard University. E-mail: s.goodman@neu.edu. 